Vol. 6 (1997): 363-369.

\title{
The effects of ridging, row-spacing and seeding rate on carrot yield
}

\author{
Sanna-Liisa Taivalmaa \\ Agricultural Research Centre of Finland, Institute of Horticulture, Hyrköläntie 122, FIN-32810 Peipohja, \\ Finland, current address: Ministry of Agriculture and Forestry, PO Box 232, FIN-00171 Helsinki, \\ Finland, e-mail: sanna.taivalmaa@mmm.fi
}

Heikki Talvitie

Agricultural Research Centre of Finland, Institute of Horticulture, Hyrköläntie 122, FIN-32810 Peipohja, Finland

\begin{abstract}
Cool, wet spring weather often delays the early growth of carrots (Daucus carota L.) in northern Europe. This effect may be partly obviated by sowing in ridges. Many types of ridges are used, but the most suitable for carrot cultivation under the conditions prevailing in northern Europe has yet to be determined. The effects of ridging, seeding rate and sowing system on the yield and visible quality of carrots were therefore studied in the field during three years. The highest yields were recorded for carrots sown in double rows on a narrow ridge. The effect of sowing system on mean root weight differed depending on the ridging regime. The mean weight of roots was higher for carrots cultivated on broad ridges than in other systems. Seeding rate had the most significant effect on mean root weight. For industrial purposes it is recommended that carrots be cultivated on broad ridges in double rows at low seeding rates with irrigation. The optimal cultivation technique for carrots destined for the fresh vegetable market would be narrow ridges sown in double rows at high seeding rates. The ridging system, seeding rate and row spacing did not appear to affect the external quality of roots. More detailed studies should be carried out to establish the effects of abiotic growth factors under different ridging regimes.
\end{abstract}

Key words: ridge, seeding rate, sowing

\section{Introduction}

A change in practice among vegetable producers, carrot producers in particular, from flat bed to ridge cultivation, has become commonplace in Finland. The seeding rate and the sowing system depend on the end-use requirements for carrots - the fresh market favours small carrots and the food industry larger ones. There is a significant correlation between plant density and carrot size. 


\section{AGRICULTURAL AND FOOD SCIENCE IN FINLAND}

Taivalmaa, S.-L. \& Talvitie, H. The effects of ridging, row-spacing and seeding rate on carrot yield

Low soil temperatures and wet soil in spring often delay the germination and early growth of carrot plants. Radke (1982) and Mahrer and Avissar (1985) noted that ridged soil dried faster than non-ridged. The soil temperature is also potentially higher in ridges than on the flat (Gupta et al. 1990), and small ridges counteract slaking to a certain degree (Schoneveld 1990). According to Tisdall and Hodgson (1990), the better aeration characteristic of soil in ridges promotes higher yields than cultivation on the flat. A change in soil surface configuration from unridged to ridged would therefore allow earlier sowing and promote earlier growth of carrot plants in the northern European climate.

Carrot yields are heavily dependent on plant density: in general the higher the plant density, the higher the yield (Kepka et al. 1978, Salter et al. 1979, Salter et al. 1980, Mack 1980, Dragland 1986, McCollum et al. 1986). Benjamin (1982) reported that high plant density magnifies any variation already present in the seedling population. Mean root weight (Hole et al. 1984, Schoneveld 1990) and the mean length and diameter of marketable roots decreased with an increase in plant density (McCollum et al. 1986).

Row arrangement has been shown to affect total carrot yields (Kepka et al. 1978, Salter et al. 1979, Salter et al. 1980, Benjamin 1984) but not the length and diameter of marketable carrots. (McCollum et al. 1986).

There is limited knowledge about the most suitable cultivation technique for carrots grown in ridges in Finland. A wide range of ridge types, seed densities and sowing systems are currently used, but little attention has been paid to the fact that the cultivation method in fact depends on whether the carrots are destined for industrial or fresh markets.

The aim of this study was to investigate the effect of ridging (flat bed, narrow ridge and broad ridge), seeding rate (target plant densities 40, 50, 60 and 70 roots $/ \mathrm{m}^{2}$ ) and sowing system (single row, double row and band) on the quantity and external quality of carrot yield.

\section{Material and methods}

The field experiments were conducted at Satakunta experimental station, western Finland $\left(61^{\circ} 17^{\prime} \mathrm{N}, 22^{\circ} 14^{\prime} \mathrm{E}\right)$ during 1990, 1991 and 1992. The experimental design was a split-split plot of four replicate blocks. The main plots comprised three soil surface configurations (flat bed, narrow and broad ridge), the subplots four target plant densities $\left(40,50,60\right.$ and 70 roots $\left./ \mathrm{m}^{2}\right)$ and the sub- subplots three sowing systems (single row, double row and band). The single row-broad ridge combination was omitted, because it is not an economically viable alternative in ridge cultivation owing to the area it requires in relation to the amount of carrots grown.

The soil type was fine sand with $\mathrm{pH}$ 5.9. The soil was formed into narrow ridges (width of base $49 \mathrm{~cm}$, height $23 \mathrm{~cm}$ ) and broad ridges (width of base $75 \mathrm{~cm}$, height $29 \mathrm{~cm}$ ) using a Rumptstad rotary tiller with soil former. The peak of both types of ridge was $15 \mathrm{~cm}$ broad. Plots with flat beds and narrow ridges measured $3.2 \mathrm{~m}^{2}$, and those with broad ridges $4.9 \mathrm{~m}^{2}$.

The carrots, cv. Fontana BZ, were sown in early May each year with a pneumatic sowing machine (Gaspardo). The seeding rate was based on $70 \%$ emergence to produce $40,50,60$ or 70 plants $/ \mathrm{m}^{2}$. The width of the band and interrow space in the double row system was $7 \mathrm{~cm}$. Sowing depth was $1-1.5 \mathrm{~cm}$. Before sowing, granular compound NPK fertilizer (10-7-14 with trace elements) was applied at a rate of $80 \mathrm{~kg} \mathrm{~N} / \mathrm{ha}$, $56 \mathrm{~kg} \mathrm{P} / \mathrm{ha}$ and $112 \mathrm{~kg} \mathrm{~K} / \mathrm{ha}$. At the beginning of August $20 \mathrm{~kg} \mathrm{~N} / \mathrm{ha}$ was applied and the earthing-up was done. Weeds were controlled with Gesagard (prometryn $500 \mathrm{~g} / \mathrm{kg}$ ) or Lurox (linuron $500 \mathrm{~g} / \mathrm{kg}$ ) once a year according to manufacturers' instructions and later by hand-weeding. Insects were controlled with applications of Malasiini (malathion $513 \mathrm{~g} / \mathrm{l}$ ) and Ripcord (sypermetrin $100 \mathrm{~g} / \mathrm{l}, 3-5$ times year).

Tap roots were hand-harvested at the beginning of October every year. The size of the harvested area for flat beds and narrow ridges was $2.5 \mathrm{~m}^{2}$ and for broad ridges $3.8 \mathrm{~m}^{2}$. The tap roots 
Vol. 6 (1997): 363-369.

Table 1. Total and marketable yields of carrots under various management regimes. Means (+ S.E.) Marked with the same letter do not differ $(\mathrm{P}<0.05)$. Main plots (soil surface configuration), subplots (target plant densities) and subsubplots (sowing system) were tested within each year.

\begin{tabular}{|c|c|c|c|c|c|c|c|c|}
\hline \multirow[b]{3}{*}{ Treatments } & & \multicolumn{7}{|c|}{ Yields (t/ha) } \\
\hline & & \multicolumn{2}{|c|}{1990} & \multicolumn{2}{|c|}{1991} & \multicolumn{2}{|c|}{1992} & \multirow[b]{2}{*}{ D.F. } \\
\hline & & Marketable & Total & Marketable & Total & Marketable & Total & \\
\hline \multirow[t]{3}{*}{$\begin{array}{l}\text { Soil surface } \\
\text { configuration }\end{array}$} & flat & $56.2 \pm 2.08 \mathrm{a}$ & $69.3 \pm 2.66 \mathrm{a}$ & $60.6 \pm 1.96 \mathrm{a}$ & $74.4 \pm 2.09 \mathrm{a}$ & $30.1 \pm 1.72 \mathrm{a}$ & $41.3 \pm 1.92 b$ & \\
\hline & narrow ridge & $54.0 \pm 3.31 \mathrm{a}$ & $66.7 \pm 3.31 \mathrm{a}$ & $61.7 \pm 2.08 \mathrm{a}$ & $74.5 \pm 2.36 \mathrm{a}$ & $32.1 \pm 1.40 \mathrm{a}$ & $45.0 \pm 1.65 \mathrm{a}$ & 6 \\
\hline & broad ridge & $56.7 \pm 2.34 \mathrm{a}$ & $68.6 \pm 2.11 \mathrm{a}$ & $56.6 \pm 1.18 \mathrm{a}$ & $66.2 \pm 1.29 \mathrm{~b}$ & $30.1 \pm 1.47 \mathrm{a}$ & $38.9 \pm 1.53 \mathrm{c}$ & \\
\hline \multirow[t]{4}{*}{ Target plant density' } & 40 & $47.9 \pm 3.05 c$ & $60.7 \pm 3.10 \mathrm{c}$ & $57.9 \pm 2.36 \mathrm{a}$ & $70.4 \pm 3.01 \mathrm{a}$ & $26.9 \pm 1.45 \mathrm{a}$ & $38.7 \pm 1.86 \mathrm{a}$ & \\
\hline & 50 & $52.3 \pm 3.35 \mathrm{a}$ & $65.9 \pm 3.21 \mathrm{~b}$ & $60.8 \pm 2.03 \mathrm{a}$ & $72.8 \pm 1.99 \mathrm{a}$ & $30.3 \pm 1.89 \mathrm{a}$ & $40.5 \pm 1.96 \mathrm{a}$ & \\
\hline & 60 & $59.9 \pm 2.49 \mathrm{ab}$ & $71.9 \pm 2.65 \mathrm{a}$ & $60.8 \pm 2.26 \mathrm{a}$ & $72.7 \pm 2.47 \mathrm{a}$ & $33.3 \pm 1.75 \mathrm{a}$ & $43.5 \pm 1.89 \mathrm{a}$ & 27 \\
\hline & 70 & $62.1 \pm 3.07 \mathrm{ab}$ & $74.0 \pm 2.97 \mathrm{a}$ & $60.6 \pm 2.40 \mathrm{a}$ & $73.6 \pm 2.67 \mathrm{a}$ & $33.7 \pm 1.93 \mathrm{a}$ & $45.6 \pm 2.42 \mathrm{a}$ & \\
\hline \multirow[t]{3}{*}{ Sowing system ${ }^{2}$} & single & $49.7 \pm 2.31$ & $62.0 \pm 2.29$ & $54.1 \pm 1.98$ & $66.5 \pm 2.09$ & $29.7 \pm 1.86$ & $41.2 \pm 2.2$ & \\
\hline & double & $68.2 \pm 2.17 \mathrm{a}$ & $80.4 \pm 2.16 \mathrm{a}$ & $65.4 \pm 1.78 \mathrm{a}$ & $77.5 \pm 2.26 \mathrm{a}$ & $32.7 \pm 1.53 \mathrm{a}$ & $43.9 \pm 1.69 \mathrm{a}$ & 72 \\
\hline & band & $46.8 \pm 2.27 b$ & $59.9 \pm 2.26 \mathrm{~b}$ & $58.5 \pm 1.63 \mathrm{~b}$ & $71.1 \pm 1.81 \mathrm{~b}$ & $30.2 \pm 1.40 \mathrm{~b}$ & $40.9 \pm 1.64 b$ & \\
\hline
\end{tabular}

' plants $/ \mathrm{m}^{2}$

${ }^{2}$ The single row sowing system was not included in the statistical contrast examination of the sowing system because the combination "broad ridge-single row sowing system" was lacking.

were weighed individually and classified according to commercial criteria. The marketable yield included tap roots weighing at least $40 \mathrm{~g}$ with no external defects.

There were large differences in weather conditions at seedling emergence time during the study period. The coldest year was 1991, when the heat sum was only 175 degrees by the middle of June, whereas it was 321 and 376 in 1990 and 1992, respectively. The cumulative precipitation from 1 May until 10 June was also highest in 1991, $58 \mathrm{~mm}$, whereas in 1990 and 1992 it was only 18 and $8 \mathrm{~mm}$, respectively. The growing season following emergence was cold and wet in 1991, but warm and fairly damp in 1990 and 1992.

The total yield, marketable yield, mean weight of roots and proportion of branched carrots were subjected to split-split plot analyses of variance (Steel and Torrie 1981, Ranta et al. 1991, SAS Institute 1985) using the GLM procedure. Treatment means were compared using Tukey's HSD test and contrast examination. The differences between treatment means were considered significant at $\mathrm{P}<0.05$.

\section{Results}

\section{Total and marketable yield}

The effect of soil surface configuration on carrot yield was statistically significant in 1991 $(\mathrm{P}=0.02)$ and $1992(\mathrm{P}=0.05)$, with narrow ridges giving the highest yield in both years. Marketable yield was not affected in any year (Table 1). The average marketable yields were $55.7 \mathrm{t} / \mathrm{ha}$, $59.6 \mathrm{t} / \mathrm{ha}$ and $30.7 \mathrm{t} / \mathrm{ha}$ in 1990,1991 and 1992 , respectively.

Carrot yield increased with an increase in the seeding rate each year, but the difference was significant for marketable $(\mathrm{P}=0.009)$ and total $(\mathrm{P}=0.01)$ yields only in 1990 . The 1.75 -fold increase in seed sown resulted in a 1.05-1.2 -fold 
Taivalmaa, S.-L. \& Talvitie, H. The effects of ridging, row-spacing and seeding rate on carrot yield

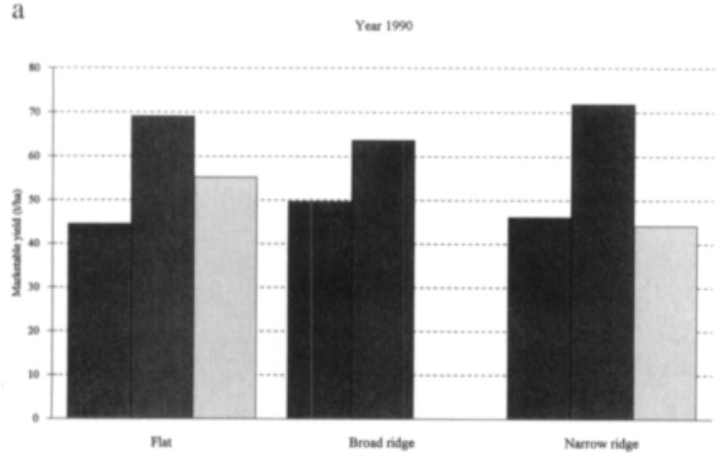

b

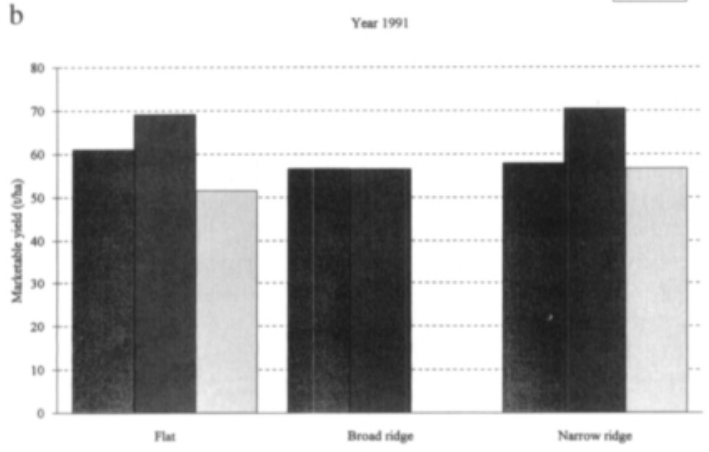

Fig. 1. The interaction between soil surface configurations and sowing systems for marketable yield in a) 1990 $(\mathrm{P}=0.002)$, b) $1991(\mathrm{P}=0.03)$.

increase in yield. The increase in yields was greatest between target densities of 50 and 60 plants $/ \mathrm{m}^{2}$ in 1990 and 1992 , but between 40 and 50 plants $/ \mathrm{m}^{2}$ in 1991 . The highest average plant populations were obtained when double rows were sown. The target plant populations, assessed during seeding on the basis of $70 \%$ emergence, were reached only in 1991, when conditions during seedling emergence were very damp.

The sowing system affected marketable and total yields each year $(\mathrm{P} \leq 0.01)$. The double row sowing system improved the yield in each soil surface configuration (Table 1). There were also statistically significant interactions between soil forming and sowing system in marketable yield and total yield in 1990 and 1991 ( $\mathrm{P} \leq 0.04)$ (Fig. 1). The difference in yields between double row and band sowing systems was small in ridges in 1991 and 1992; in all years single rows sown in ridges gave the smallest yield.

\section{Quality of yield}

The mean individual root weight of carrots was $161 \mathrm{~g}, 106 \mathrm{~g}$ and $107 \mathrm{~g}$ in 1990, 1991, 1992, respectively. The soil surface configuration influenced mean root weight each year $(\mathrm{P}<0.02)$ (Fig. 2). Seeding rate had a significant effect on mean root weight in 1990 and $1991(\mathrm{P}<0.01)$. The lowest seeding rate resulted in the highest mean root weight each year: $190 \mathrm{~g}, 123 \mathrm{~g}$ and $126 \mathrm{~g}$ in 1990, 1991, 1992, respectively. The mean root weights at the highest seeding rate were $139 \mathrm{~g}, 89 \mathrm{~g}$ and $90 \mathrm{~g}$ in 1990, 1991, 1992, respectively.

The sowing system affected the mean root weight only in 1990, when the highest mean root weight was recorded for band sowing, $183 \mathrm{~g}$; it was $173 \mathrm{~g}$ in single and $143 \mathrm{~g}$ in double rows $(\mathrm{P}<0.001)$. There was a statistically significant interaction between soil surface configuration and sowing system each year $(\mathrm{P}<0.02)$ (Fig. 2).

The average amount of branched carrots was $160 \mathrm{~kg} / \mathrm{ha}, 80 \mathrm{~kg} / \mathrm{ha}$ and $150 \mathrm{~kg} / \mathrm{ha}$ in 1990,1991 , 1992 , respectively. There were only minor differences between treatments in this property. The amount of branched carrots was not analysed statistically. The dry matter content of tap roots ranged from 9.7 to $11 \%$ and was each year highest in the carrots grown on narrow ridges.

\section{Discussion}

Each soil surface configuration requires its own cultivation technique for the optimal production of carrots. In this experiment the highest yields were obtained with narrow ridges and double rows. With the exception of the size of tap roots, 


\section{AGRICULTURAL AND FOOD SCIENCE IN FINLAND}

Vol. 6 (1997): 363-369.

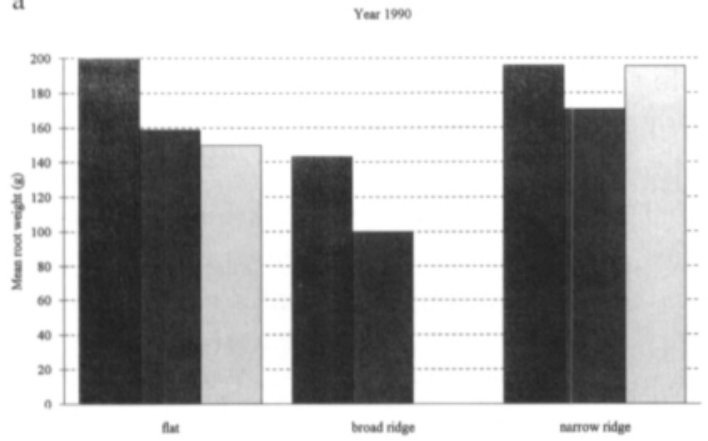

c

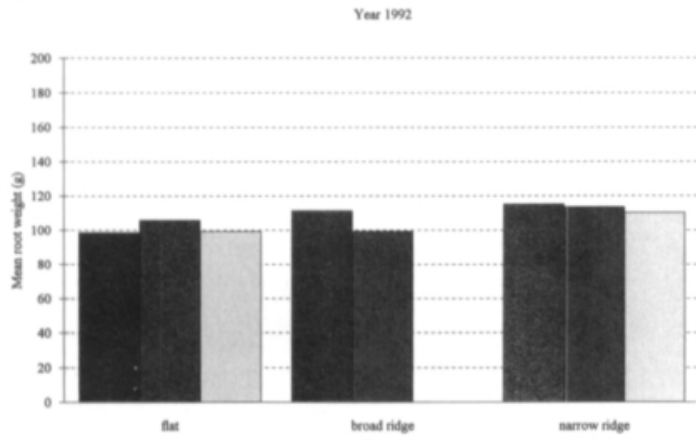

the effects of the factors studied on the quality of yield were small.

One of the main factors affecting yield was the weather during seedling emergence and its effect on emergence. Good emergence resulted in a good yield, suggesting that good emergence is vital for all cultivation techniques. It seems that wet weather does not favour cultivation in broad ridges, whereas the use of narrow ridges apparently provides a suitable environment for carrot development, irrespective of the weather. However, irrigation is becoming increasingly popular among vegetable farmers, enabling optimal soil moisture to be maintained during seedling emergence.

The double row system promoted good carrot yields under all conditions, although the results of Salter et al. (1979), Salter et al. (1980) and Mack (1980) suggested that row spacing had little effect on root yields in experiments made on the flat. Kepka et al. (1978) considered band sowing the most suitable method for carrot growing. The usefulness of this method is, however, b
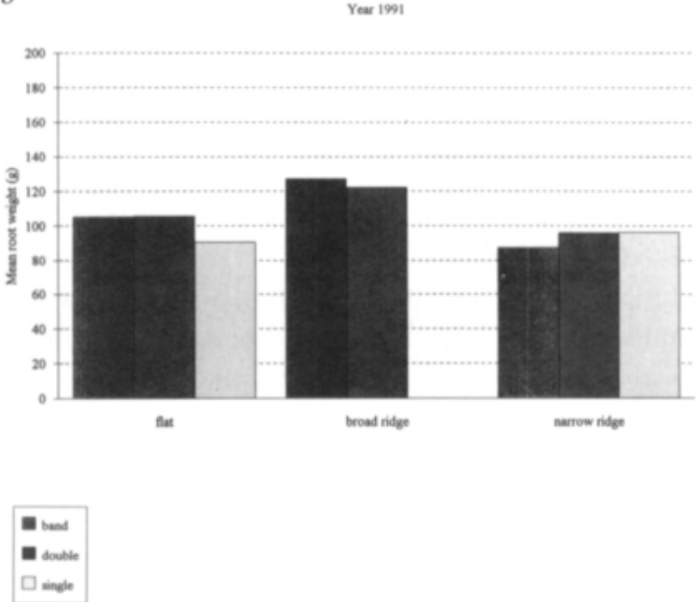

Fig. 2. The interaction between soil configurations and sowing systems for mean root weight in a) 1990 ( $\mathrm{P}=0.003)$, b) $1991(\mathrm{P}=0.002), \mathrm{c}) 1992(\mathrm{P}=0.02)$.

impaired by a reduced ability to maintain soil moisture, most likely due to differences in the width of the roller wheel in sowing machines; that of the double row sower being narrow and therefore more inclined to press the seed deep into moist soil than the broad roller wheel used during band sowing. Our study was made in fine sand, without irrigation. The effect of soil surface configuration may differ from one soil type to another. On the basis of the results of these experiments double row or band sowing can be recommended for ridge cultivation. If, however, the soil is dry during seedling emergence, band sown carrots should preferably be irrigated. With flat beds even single rows can give satisfactory yields.

The mean root weight of carrots was influenced most effectively by changing the seeding rate - the higher the seeding rate, the smaller the roots and the higher the yields. This effect of seeding rate on the mean root weight of carrots is consistent with previously reported results (McCollum et al. 1986, Schoneveld 1990), but 


\section{AGRICULTURAL AND FOOD SCIENCE IN FINLAND}

Taivalmaa, S.-L. \& Talvitie, H. The effects of ridging, row-spacing and seeding rate on carrot yield

in general, the effect of seeding rate on yields was small, being significant only in 1990. This finding supports the results of Benjamin and Sutherland (1992), who noted that a tenfold increase in density resulted in a twofold increase in yield. Our results are also compatible with those of Mack (1980), who found that although the total yields resulting from different seeding rates were not significantly different, there was a significant difference when yields were classified by size.

The effect of sowing system on mean root weight differed between soil surface configurations. The mean root weight of carrots cultivated in flat beds and narrow ridges was similar in all years, but it was higher for carrots grown on broad ridges. The mean root weight correlates with the size of carrots, even though the correlation is not perfect.

The sowing system did not affect the external quality of roots. Only in 1990 was there a difference in mean root size between band sowing and double row sowing. This finding attributed to the plant population at harvest, which was clearly smaller for band sown carrots than carrots sown in double rows, presumably as a result of poor emergence. Kepka et al. (1978) found more split and branched carrots in single rows, but we noted no such effect in our experiments.

Fresh market carrots are best produced by a cultivation technique that requires a high seeding rate on double rows and narrow ridges, since a large number of small tap roots are needed.
The optimal target plant density in this case is at least $60-70$ roots $/ \mathrm{m}^{2}$ Dragland (1986) likewise recommended 70 plants $/ \mathrm{m}^{2}$, whereas the recommendation of Kepka et al. (1978) was twice as high (150 plants $\left./ \mathrm{m}^{2}\right)$.

Carrots grown for industrial processing are best cultivated on broad ridges, in double rows and at lower seeding rates than carrots used for fresh market purposes. The target plant density should be 50 roots $/ \mathrm{m}^{2}$ (or less) depending on the variety. The mean root weight of carrots grown on ridges is high. Moreover, in the experience of growers, carrots grown on broad ridges tend to be longer and larger than those grown in other soil surface configurations. These long roots are not suitable for packing in small plastic bags but are ideal for industrial purposes.

Future studies are needed on abiotic growth factors, temperature and moisture in particular, in different soil surface configurations and on different soil types. We also lack basic knowledge of the abiotic conditions that prevail in ridges of different types. The effect of ridging on the internal quality of carrots should also be investigated.

Acknowledgements. We thank Martti Linnainmaa, Jari Pärssinen, Helena Palo, Rauno Kauppila and Terttu Kauppila for their excellent technical assistance during the experiments. We also thank Dr Aino-Maija Evers for her valuable comments on the manuscript. We are particularly grateful to Dr Jonathan Robinson for his comments and for revising the text.

\section{References}

Benjamin, L.R. 1982. Some effects of differing times of seedling emergence, population density and seed size on root-size variation in carrot populations. Journal of Agricultural Science 98: 537-545.

- 1984. The relative importance of some sources of root weight variation in a carrot crop. Journal of Agricultural Science, Cambridge 102: 69-77.

- \& Sutherland, R.A. 1992. Control of mean root weight in carrots (Daucus carota) by varying within- and between-row spacing. Journal of Agricultural Science 119: 59-70.
Dragland, S. 1986. Plantetetthet og radavstand i gulrot. Forskning og forsok i landbruket 37: 139-145.

Gupta, S.C., Radke, J.K., Swan, J.B. \& Moncrief, J.F. 1990. Predicting soil temperatures under a ridge-furrow system in the U. S. corn belt. Soil \& Tillage Research 18: 145-165.

Hole, C.C., Thomas, T.H., Barnes, A., Scott, P.A. \& Rankin,W.E.F. 1984. Dry matter distribution between shoot and storage root of carrot, parsnip, radish and red beet. Annals of Botany 53: 625-631.

Kepka, A., Umiecka, L. \& Fajkowska, H. 1978. The influ- 
Vol. 6 (1997): 363-369.

ence of row spacing and plant density in rows on the yield of carrots and root quality. Acta Horticulturea 72: 217-224.

Mack, H.J. 1980. Effect of row spacing on processing carrot root yields. HortScience 15, 2: 144-145.

Mahrer, Y. \& Avissar, R. 1985. A numerical study of effects of soil surface shape upon the soil temperature and moisture regimes. Soil Science 139, 6: 483-490.

McCollum, T.G., Locascio, S.J. \& White, J.M. 1986. Plant density and row arrangement effects on carrot yields. Journal of American Society of Horticultural Science 111, 5: 648-651.

Radke, J.K. 1982. Managing early season soil temperatures in the northern corn belt using configured soil surfaces and mulches. Journal of American Soil Science Society 46: 1067-1071.

Ranta, E., Rita, H. \& Kouki, J. 1991. Biometria. Tilastotiedettä ekologeille. 3rd ed. Helsinki, Yliopistopaino. $569 \mathrm{p}$.
Salter, P.J., Currah, I.E. \& Fellows, J.R. 1979. The effects of plant density, spatial arrangement and time of harvest on yield and root size in carrots. Journal of Agricultural Science 93: 431-440.

- , Currah, I.E. \& Fellows, J.R. 1980. Further studies on the effects of plant density, spatial arrangement and time of harvest on yield and root size in carrots. Journal of Agricultural Science 94: 465-478.

SAS Institute Inc. 1985. SAS user's guide. Statistics. Version 5 edition. Cary. North Caroline.

Schoneveld, J.A. 1990. Research aimed at a reliable emergence of carrots. Acta Horticulturae 267: 199208.

Steel, R.G.D. \& Torrie, J.H. 1981. Principles and procedures of statistics - A biometric approach. 2nd ed. Singapore, McGraw-Hill International Book Company. $633 \mathrm{p}$.

Tisdall, J.M. \& Hodgson, A.S. 1990. Ridge tillage in Australia: a review. Soil \& Tillage Research 18: 127-144.

\title{
SELOSTUS
}

\section{Maan muotoilun, kylvötavan ja siementiheyden vaikutus porkkanan satoon}

\author{
Sanna-Liisa Taivalmaa ja Heikki Talvitie \\ Maatalouden tutkimuskeskus
}

Tutkimuksella selvitettiin maan muotoilun (tasamaa, pieni ja iso harju), kylvötavan (yksirivi, kaksirivi ja nauha) sekä siementiheyden $(40,50,60$ ja 70 taimea/ $\mathrm{m}^{2}$ ) vaikutusta porkkanan sadon määrään ja ulkoiseen laatuun. Jokainen maan muotoilutapa vaatii oman viljelytekniikan, jonka valintaan vaikuttaa se mihin tarkoitukseen porkkanoita viljellään. Taimettumisen onnistuminen oli yksi tärkeimmistä sadon määrään vaikuttavista tekijöistä. Suurin sato saatiin pienestä harjusta. Kaksoisrivikylvö oli sopivin kylvötapa kaikilla maanmuotoilutavoilla.

Porkkanan juuren kokoon vaikutti eniten siementiheys; mitä suurempi tiheys, sitä pienempiä juuria. Maanmuotoilu, kylvötapa tai kylvötiheys eivät vai- kuttaneet haarautuneiden ja haljenneiden juurten määrään. Viljeltäessä porkkanoita tuorekäyttöön halutaan paljon kooltaan melko pieniä porkkanoita. Tällöin sopivin maanmuotoilutapa on tasamaa tai pieni harju ja taimitiheys tulisi olla $60-70$ porkkanaa/ $\mathrm{m}^{2}$. Pieneen harjuun paras kylvötapa on kaksirivikylvö, mutta myös nauhakylvölla saadaan hyvä sato, jos maaperä on taimettumisaikana tarpeeksi kostea. Tasamaalla myös yksirivikylvöllä voidaan saada tyydyttävä sato. Isoissa harjuissa porkkanoiden keskipaino on suurempi kuin muilla maanmuotoilutavoilla viljeltyjen porkkanoiden, joten iso harju sopii hyvin teollisuusporkkanan tuotantoon. Tällöin sopiva taimitiheys tulisi olla $40-50$ porkkanaa/ $\mathrm{m}^{2}$. 